\title{
Synthesis of Dynamic 2-Ethoxycarbonyl-4H-3,1-Benzoxazin-4-one and its Behavior Towards Nitrogen Nucleophiles
}

\author{
M. A. El-Hashash ${ }^{\mathrm{a}}$ and Y. A. El-Badry*b
}

${ }^{a}$ Organic Chemistry Dep., Faculty of Science, Ain Shams University, 11566 Abbasseya, Cairo, Egypt

${ }^{b}$ Organic chemistry Lab, Faculty of Specific Education, Ain Shams University, 11566 Abbasseya, Cairo, Egypt yaser75moemen@yahoo.com

\begin{abstract}
The behavior of 2-ethoxycarbonyl-4H-3,1-benzoxazin-4-one and its behavior towards nitrogen nucleophiles namely, hydrazine hydrate, formamide, benzylamine, ethylamine, piperidine, ethanol amine, o-phenylenediamine, and glucosamine hydrochloride has been investigated. Also the reaction of 3-[aminoquinazolin-4(3H)-one-2-yl]formic acid hydrazide with aromatic aldehydes and phenylisothiocyanate has been discussed. The structure of the prepared compounds are elucidated using physical and spectral data like, FT-IR, ${ }^{1} \mathrm{HNMR}$, and mass spectroscopy.
\end{abstract}

\section{Indexing terms/Keywords}

Dynamic 4H-3; 1-benzoxazin-4-one, 2,3-disubstituted quinazolinones; Nitrogen nucleophiles; Triazinoquinazoline.

\section{Council for Innovative Research}

Peer Review Research Publishing System

\section{Journal: Journal of Advances in Chemistry}

\author{
Vol. 4, No. 3 \\ editor@cirworld.com \\ www.cirworld.com, member.cirworld.com
}




\section{INTRODUCTION}

Potent benzoxazinones are inhibitors for human leukocyte elastase (HLE) [1], human Cathepsin G, and bovine chymotrypsin [2]. Also, the inhibition of Chymotrypsin-like and Elastase-like serine proteases by 4H-3,1-benzoxazin-4ones has been investigated [3]. In addition many fused pyrimidines such as quinazolinones have been reported to exhibit anti-inflammatory [4], antimicrobial [5], anticancer [6], and antimalarial [7] activities. Quinazolin-4(3H)-ones are frequently encountered unit in natural products such as L-Vasicinone[8] and Chrysogine [9]. For the above findings and in continuation of our program [10-15] on the synthesis of novel heterocyclic systems exhibiting biological activity, we synthesis a varieties of quinazolinone derivatives via the interaction of the benzoxazinone derivative 2 with different nitrogen nucleophiles. Firstly, with the aim of obtaining more precise information about the course of the reaction and some interesting pharmaceutical compounds. Also compound 2 so called dynamic benzoxazinone derivative due to the electron attracting power of the ethoxycarbonyl group at the 2-position increases the electronically unsaturated character of the oxazinone ring and increases its affinity towards nucleophiles. This is the second target which we want to prove it in this study.

\section{EXPERIMENTAL}

\section{General procedure}

Reagents and solvents were used as obtained from the supplier without further purification. All melting points reported are uncorrected and were determined on a Stuart electric melting point apparatus. Elemental analysis were carried out in the Micro Analytical Center, Cairo University, Giza, Egypt. Thin-layer chromatography (TLC) was performed on Merk TLC aluminium sheets silica gel $60 \mathrm{~F}_{254}$ with detection by UV quenching at $254 \mathrm{~nm}$. ${ }^{1} \mathrm{H}$ NMR spectra were recorded on a Bruker $400 \mathrm{MHz}$ spectrometer, with residual proton signal of the deuterated solvent as the internal reference $\left(\delta_{\mathrm{H}}=7.26 \mathrm{ppm}\right.$ for $\mathrm{CDCl}_{3}$ and $\delta_{\mathrm{H}}=2.51 \mathrm{ppm}$ for DMSO-d $\mathrm{d}_{6}$ ). Chemical shifts $(\delta)$ are given in parts per million (ppm). IR spectra were recorded on Nicolet Impact 400D FT-IR apparatus using OMNIC program and are reported in terms of frequency of absorption (cm $\left.{ }^{1}\right)$. EIMS were recorded on a gas chromatographic GCMS - Qploopx Shimadzu (Japan, 1990)

\section{Formation 1 and 2}

A solution of anthranilic acid $(1.37 \mathrm{~g}, 0.1 \mathrm{~mol})$ and diethyloxalate $(1.46 \mathrm{~g}, 0.1 \mathrm{~mol})$ in $n$-butanol $(30 \mathrm{~mL})$ was refluxed for $6 \mathrm{~h}$. The solid that separated after concentration was filtered off and crystallized from DMF to give 1 as colorless crystals. The solid that separated after concentration the mother liquor was filtered off and crystallized from $n$-BuOH to give the benzoxazinone 2 as pale yellow crystals.

2-(Ethoxycarbonylformylamino)benzoic acid (1): Yield 65\%. M.p. $>300{ }^{\circ} \mathrm{C}$. IR $(\mathrm{KBr}): 1675,1701,1744$ (CO), $3266 \mathrm{~cm}^{-1}$ (CH-arom.). ${ }^{1} \mathrm{H}$ NMR (DMSO-d $): \delta 1.00$ (t, J=7Hz, 3H, $\left.\mathrm{CH}_{3}\right), 4.13\left(\mathrm{q}, \mathrm{J}=7 \mathrm{~Hz}, 2 \mathrm{H}, \mathrm{CH}_{2}\right), 6.24(\mathrm{brs}, 1 \mathrm{H}$, $\mathrm{NH}, \mathrm{D}_{2} \mathrm{O}$ exchangable), 7.32-8.14 (m, 4H, Ar-H), 12.1 (s, $\left.1 \mathrm{H}, \mathrm{OH}\right)$. Anal. Calc. for $\mathrm{C}_{11} \mathrm{H}_{11} \mathrm{NO}_{5}(237): \mathrm{C} \mathrm{55.69,} \mathrm{H} 4.64, \mathrm{~N}$ 5.90; found: C 55.72, H 4.70, N 6.00 .

2-Ethoxycarbonyl-4H-3,1-benzoxazin-4-one (2): Yield 74\%. M.p. $130{ }^{\circ} \mathrm{C} . \mathrm{IR}(\mathrm{KBr}): 1721,1744 \mathrm{~cm}^{-1}(\mathrm{CO}) .{ }^{1} \mathrm{H}$ $\operatorname{NMR}\left(\mathrm{DMSO}-\mathrm{d}_{6}\right): \delta 1.15\left(\mathrm{t}, \mathrm{J}=7 \mathrm{~Hz}, 3 \mathrm{H}, \mathrm{CH}_{3}\right), 4.16\left(\mathrm{q}, \mathrm{J}=7 \mathrm{~Hz}, 2 \mathrm{H}, \mathrm{CH}_{2}\right), 7.29-7.94(\mathrm{~m}, 4 \mathrm{H}, \mathrm{Ar}-\mathrm{H})$. Anal. Calc. for $\mathrm{C}_{11} \mathrm{H}_{9} \mathrm{NO}_{4}$ (219): C 60.27, H 4.10, N 6.39; found: C 60.34, H 4.18, N 6.44.

\section{(Quinazolin-4(3H)-one-2-yl)formamide (3)}

A solution of $2(2.19 \mathrm{~g}, 0.1 \mathrm{~mol})$ and formamide $(10 \mathrm{~mL})$ was heated under reflux for $3 \mathrm{~h}$. The reaction mixture was diluted with $\mathrm{H}_{2} \mathrm{O}$ and the solid that separated filtered off and crystallized from DMF to give 3 as colorless crystal. Yield $69 \%$. M.p. $>300{ }^{\circ} \mathrm{C}$. IR (KBr): 1661, 1680 (CO), 3137, $3200 \mathrm{~cm}^{-1}$ (NH). ${ }^{1} \mathrm{H}$ NMR (DMSO-d $): \delta 7.36-8.03(\mathrm{~m}, 4 \mathrm{H}, \mathrm{Ar}-\mathrm{H}), 9.39(\mathrm{brs}, 2 \mathrm{H}$, $\mathrm{NH}_{2}, \mathrm{D}_{2} \mathrm{O}$ exchangable), 13.9 (brs, $1 \mathrm{H}, \mathrm{NH}, \mathrm{D}_{2} \mathrm{O}$ exchangable). Anal. Calc. for $\mathrm{C}_{9} \mathrm{H}_{7} \mathrm{~N}_{3} \mathrm{O}_{2}$ (189): C 57.14, H 3.70, N 22.22; found: C 57.50, H 4.00, N 22.25.

\section{(3-Benzyl-quinazolin-4(3H)-one)- $\mathrm{N}$-benzylformamide (4)}

A mixture of $2(2.19 \mathrm{~g}, 0.01 \mathrm{~mol})$ and benzylamine $(1.06 \mathrm{~g}, 0.01 \mathrm{~mol})$ in ethanol $(30 \mathrm{~mL})$ was heated under reflux for $3 \mathrm{~h}$. The solid that separated after cooling was filtered off and crystallized from ethanol to give $\mathbf{4}$ as colorless crystals. Yield $62 \%$. M.p. $198{ }^{\circ} \mathrm{C}$. IR (KBr): 1661, 1672 (CO), $3210 \mathrm{~cm}^{-1}(\mathrm{NH})$. Anal. Calc. for $\mathrm{C}_{23} \mathrm{H}_{19} \mathrm{~N}_{3} \mathrm{O}_{2}(369)$ : C 74.79, $\mathrm{H} 5.14, \mathrm{~N} 11.38$; found: C 74.79, H 5.35, N 11.46. MS: m/z 370[M+] (19.2\%), 278(26.8\%), 264(100\%), 235(13.4\%), 134 (39.8\%).

\section{2-[(2-Alkylamino-2-alkylcarbamoyl)azavinyl]benzoic acid (5a-c)}

An equimolar ratio of $2(0.01 \mathrm{~mol})$, appropriate amine namely, ethylamine, ethanolamine, and piperidine $(0.01 \mathrm{~mol})$ in 1,4dioxane $(30 \mathrm{~mL})$ was heated under reflux for $3 \mathrm{~h}$. The solid that separated after cooling was filtered off and crystallized from the proper solvent to give 5a-c.

2-[(2-Ethylamino-2-ethylcarbamoyl)azavinyl]benzoic acid (5a): Yield 72\% (colorless). M.p. $>300{ }^{\circ} \mathrm{C}$ (acetic acid). IR (KBr): $1605(\mathrm{C}=\mathrm{N}), 1677,1700(\mathrm{CO}), 3270(\mathrm{NH}), 3400 \mathrm{~cm}^{-1}(\mathrm{OH})$. Anal. Calc. for $\mathrm{C}_{13} \mathrm{H}_{17} \mathrm{~N}_{3} \mathrm{O}_{3}(263): \mathrm{C}$ 59.31, H 6.46, N 15.96; found: C 59.71, H 6.86, N 16.28. 
2-[(2-Hydroxyethylamino-2-hydroxyethylcarbamoyl)azavinyl]benzoic acid (5b): Yield 66\% (pale yellow). M.p. $290-292^{\circ} \mathrm{C}$ (methanol). IR (KBr): $1603(\mathrm{C}=\mathrm{N}), 1678,1700(\mathrm{CO}), 3266(\mathrm{NH}), 3450 \mathrm{~cm}^{-1}$ (chelated OH). Anal. Calc. for $\mathrm{C}_{13} \mathrm{H}_{17} \mathrm{~N}_{3} \mathrm{O}_{5}$ (295): C 52.88, H 5.76, N 14.23; found: C 52.48, H 5.56, N 14.63.

2-[(2-Piperidino-2-piperidinocarbamoyl)azavinyl]benzoic acid (5c): Yield 63\% (pale yellow). M.p. 180$182^{\circ} \mathrm{C}$ (methanol). IR (KBr): $1600(\mathrm{C}=\mathrm{N}), 1667,1690(\mathrm{CO}), 3425 \mathrm{~cm}^{-1}$ (chelated OH). Anal. Calc. for $\mathrm{C}_{19} \mathrm{H}_{25} \mathrm{~N}_{3} \mathrm{O}_{3}(343): \mathrm{C}$ 66.47, H 7.28, N 12.24; found: C 66.21, H 7.58, N 12.56.

\section{5,6-Benzo-2-oxo-1,2-dihydropyrazino[4,3-b]quinazolin-4(3H)-one (6)}

A mixture of $2(2.19 \mathrm{~g}, 0.01 \mathrm{~mol})$ and o-phenylene diamine $(1.07 \mathrm{~g}, 0.01 \mathrm{~mol})$ in toleuene $(30 \mathrm{~mL})$ was heated under reflux for $5 \mathrm{~h}$. The solid that separated after cooling was filtered off and crystallized from glacial acetic acid to give 6 as brown crystals. Yield 74\%. M.p. 297-298 ${ }^{\circ} \mathrm{C}$. IR (KBr): 1457, 1579, 1628 (ring vibration of quinazolone ring), 1672 (CO), $3280 \mathrm{~cm}$ ${ }^{1}(\mathrm{NH}) .{ }^{1} \mathrm{H}$ NMR $\left(\mathrm{CDCl}_{3}\right): \delta$ 7.31-8.36 (m, 8H, Ar-H), 10.56 (brs, $1 \mathrm{H}, \mathrm{NH}, \mathrm{D}_{2} \mathrm{O}$ exchangable). Anal. Calc. for $\mathrm{C}_{15} \mathrm{H}_{9} \mathrm{~N}_{3} \mathrm{O}$ (263): C 68.44, H 3.42, N 15.96; found: C 68.40, H 3.15, N 15.90.

\section{3-Glucosyl-2-N-glucosylcarbamoylquinazolin-4(3H)-one (7)}

A solution of $2(2.19 \mathrm{~g}, 0.01 \mathrm{~mol})$ and glucosamine hydrochloride $(2.16 \mathrm{~g}, 0.01 \mathrm{~mol})$ in pyridine $(15 \mathrm{~mL})$ was refluxed for $3 \mathrm{~h}$. The reaction mixture was poured onto ice cold dil. $\mathrm{HCl}$. The solid that separated was filtered off and crystallized from ethanol to give 7 as beige crystals. Yield $67 \%$. M.p. $290-292{ }^{\circ} \mathrm{C}$. IR $(\mathrm{KBr}): 1452,1531,1633$ (ring vibration of quinazolone ring), 1692, $1695(\mathrm{CO}), 3231(\mathrm{NH}), 3383 \mathrm{~cm}^{-1}$ (chelated $\mathrm{OH}$ ). Anal. Calc. for $\mathrm{C}_{21} \mathrm{H}_{27} \mathrm{~N}_{3} \mathrm{O}_{12}(513)$ : C 49.12, H 5.26, N 8.18; found: C 49.00, H 5.20, N 8.07. MS: m/z 351[M+- $\left.\mathrm{C}_{6} \mathrm{H}_{11} \mathrm{O}_{5}\right]$ (12.7\%), 264(43.0\%), 235(17.6\%), 206(100\%), 163(31.2\%), $134(8.9 \%)$

\section{3-Amino-2-hydrazinocarbonylquinazlin-4(3H)-one (8)}

A solution of compound $2(2.19 \mathrm{~g}, 0.01 \mathrm{~mol})$ and hydrazine hydrate $(1.5 \mathrm{~g}, 0.03 \mathrm{~mol})$ in ethanol $(30 \mathrm{~mL})$ was heated under reflux for $6 \mathrm{~h}$. The solid that separated on cooling was filtered off and crystallized from $n$-BuOH to give 8 as beige crystals. Yield $71 \%$. M.p. $260-262^{\circ} \mathrm{C}$. IR (KBr): 1453, 1517, 1630 (ring vibration of quinazolone ring), 1680, 1697 (CO), 3212,3318 $\mathrm{cm}^{-1}(\mathrm{NH})$. Anal. Calc. for $\mathrm{C}_{9} \mathrm{H}_{9} \mathrm{~N}_{5} \mathrm{O}_{2}$ (219): C 49.31, H 4.10, N 31.96; found: C 49.26, H 3.92, N 31.56.

\section{(3-Arylideneaminoquinazolin-4(3H)-one-2yl)-N-aminoformamide (9a,b)}

A solution of compound $8(2.19 \mathrm{~g}, 0.01 \mathrm{~mol})$ and aromatic aldehyde namely, benzaldehyde and/or 4-methoxybenzaldehyde $(0.015 \mathrm{~mol})$ in ethanol $(30 \mathrm{~mL})$ and few drops of piperidine was added and the reaction mixture was refluxed for $6 \mathrm{~h}$. The solid that separated after cooling was crystallized from $n-\mathrm{BuOH}$ to give $9 \mathbf{a}, \mathbf{b}$ respectively.

(3-Benzylideneaminoquinazolin-4(3H)-on-2-yl)- $N$-aminoformamide (9a): Yield $67 \%$ (brown). M.p. $>300^{\circ} \mathrm{C}$. IR (KBr): 1509, 1585, 1634 (ring vibration of quinazolone ring), 1664, 1700 (CO), $3254,3260 \mathrm{~cm}^{-1}$ (NH). ${ }^{1} \mathrm{H}$ NMR $\left(\mathrm{CDCl}_{3}\right): \delta$ 7.36-7.95 (m, 6H, Ar-H \& olefinic-H), 8.11-8.72 (m, 3H, Ar-H), $9.12(\mathrm{~s}, 1 \mathrm{H}, \mathrm{NH}), 12.79(\mathrm{~s}, 1 \mathrm{H}, \mathrm{NH}), 12.83(\mathrm{~s}$, $1 \mathrm{H}, \mathrm{NH}$ ). Anal. Calc. for $\mathrm{C}_{16} \mathrm{H}_{13} \mathrm{~N}_{5} \mathrm{O}_{2}$ (307): C 62.54, H 4.23, N 22.80; found: C 62.12, H 4.46, N 22.48.

[3-(4-Methoxybenzylideneaminoquinazolin-4(3H)-on-2-yl)- $N$-aminoformamide (9b):Yield $69 \%$ (beige). M.p. $>300{ }^{\circ} \mathrm{C}$. IR (KBr): 1419, 1507, 1601 (ring vibration of quinazolone ring), $1663(\mathrm{CO}), 3210,3249 \mathrm{~cm}^{-1}(\mathrm{NH})$. Anal. Calc. for $\mathrm{C}_{17} \mathrm{H}_{15} \mathrm{~N}_{5} \mathrm{O}_{3}$ (337): C 60.53, $\mathrm{H} 4.45, \mathrm{~N} 20.77$; found: C 60.72, $\mathrm{H} 4.32$, N 20.35.

\section{Formation of $10 a, b$}

A solution of compound $8(2.19 \mathrm{~g}, 0.01 \mathrm{~mol})$ and aromatic aldehydes namely 4-chlorobenzaldegyde and/or 4 nitrobenzaldegyde $(0.02 \mathrm{~mol})$ in dimethyl formamide $(30 \mathrm{~mL})$ was heated under reflux for $3 \mathrm{~h}$. The reaction mixture was diluted with water and the solid that separated was filtered off and crystallized from acetic acid to give 10a,b as pale yellow crystals respectively.

[3-(4-Chlorobenzylideneaminoquinazolinon-2-yl]-4-chlorobenzylideneamino formamide (10a): Yield 67\%. M.p. $237-238^{\circ} \mathrm{C}$. IR (KBr): 1401, 1516, 1558 (ring vibration of quinazolone ring), $1665(\mathrm{CO}), 3281 \mathrm{~cm}^{-1}(\mathrm{NH})$. ${ }^{1} \mathrm{H}$ NMR $\left(\mathrm{CDCl}_{3}\right): \delta$ 7.26-8.34 (m, 13H, Ar-H \& olefinic- $\left.\mathrm{H}\right), 8.79(\mathrm{~s}, 1 \mathrm{H}$, olefinic- $\mathrm{H}), 12.94(\mathrm{~s}, 1 \mathrm{H}, \mathrm{NH})$. Anal. Calc. for $\mathrm{C}_{23} \mathrm{H}_{15} \mathrm{~N}_{5} \mathrm{O}_{2} \mathrm{Cl}$ (246.4): C 59.48, $\mathrm{H} 3.23, \mathrm{~N}$ 15.08; found: C 59.48, H 3.18, N 15.51 .

[3-(4-Nitrobenzylideneaminoquinazolinon-2-yl]-4-nitrobenzylideneamino formamide (10b): Yield 59\%. M.p. 263-265 ${ }^{\circ} \mathrm{C}$. IR (KBr): 1409, 1522, 1587 (ring vibration of quinazolone ring), $1681(\mathrm{CO}), 3254 \mathrm{~cm}^{-1}(\mathrm{NH})$. Anal. Calc. for $\mathrm{C}_{23} \mathrm{H}_{15} \mathrm{~N}_{7} \mathrm{O}_{6}$ (485): C 56.90, H 3.09, N 20.20; found: C 56.38, H 3.12, N 20.46.

\section{Triazinoquinazolinone 11}

A mixture of compound $8(2.19 \mathrm{~g}, 0.01 \mathrm{~mol})$ and phenylisocyanate $(2.68 \mathrm{~g}, 0.02 \mathrm{~mol})$ in dimethyl formamide $(30 \mathrm{~mL})$ was heated under reflux for $3 \mathrm{~h}$. The reaction mixture was diluted with water and the solid that separated was filtered off and crystallized from toluene to give $\mathbf{1 1}$ as pale yellow crystals. 
Yield 66\%. M.p. $273{ }^{\circ} \mathrm{C}$. IR (KBr): $1388(\mathrm{C}=\mathrm{S}), 1691$ (CO), 3151, $3222 \mathrm{~cm}^{-1}(\mathrm{NH})$. Anal. Calc. for $\mathrm{C}_{23} \mathrm{H}_{17} \mathrm{~N}_{7} \mathrm{O}_{2} \mathrm{~S}(455): \mathrm{C}$ 60.65, H 3.73, N 21.53; found: C 60.54, H 3.60, N 21.43.

\section{RESULTS AND DISCUSSION}

2-Ethoxycarbonyl-4H-3,1-benzoxazin-4-one (2) was obtained via the interaction of diethyloxalate with anthranilic acid in boiling $n$-butanol via ring closure of isolated anthranil intermediate 1. Also the benzoxazinone derivative 2 was obtained from dehydration of compound 1 with $\mathrm{Ac}_{2} \mathrm{O}$ (Scheme 1).

Considering the structure of $4 \mathrm{H}-3,1$-benzoxazin-4-one derivatives; there are two sites available for nucleophilic attack $\mathrm{C}(2)$ and $\mathrm{C}(4)$, i.e, two different sites with partial positive charge that can lead to the opening of the oxazinone nucleus by different nucleophiles. In most cases, reclosure of the heterocyclic part of the molecule is favored and provides a new compound with interesting chemical and biological properties [16].<smiles>CCOC(=O)C(=O)Nc1ccccc1C(=O)O</smiles>

(a) Diethyloxalate, $n$-BuOH

(b) $\mathrm{Ac}_{2} \mathrm{O}$

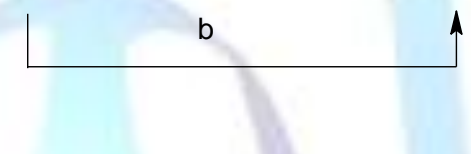

Scheme 1

In this respects, the reaction of benzoxazinone 2 with formamide or benzylamine yielded quinazolin-4(3H)-one-2ylformamide and 3-benzylquinazolin-4(3H)-one-2-yl- $N$-benzylformamide 3 and $\mathbf{4}$ respectively (Scheme 3 ). One can interpret these results as follows: the $N$-nucleophiles are attacking the benzoxazinone 2 in a fashion in which the amino group first undergoes $\mathrm{H}$-bonding to the $\mathrm{N}$-atom of the heterocycle. Then, the amino group reacts by nucleophilic addition at the activated azavinylic $\mathrm{C}(2)$ (activated by the ethoxycarbonyl group) to form an inner amidinium salt [12], which subsequently is dehydrated to give the quinazolinone derivative (Scheme 2).

On the other hand, 4H-3,1-benzoxazin-4-one 2 reacted with ethylamine, ethanolamine, and piperidine in 1,4-dioxane and yielded the corresponding 2-(disubstituted azamethylene)benzoic acid 5a-c (Scheme 3). IR spectra of compound $\mathbf{5}$ revealed strong absorption bands at $1685-1700 \mathrm{~cm}^{-1}$ attributable to $\mathrm{v}_{\mathrm{C}=\mathrm{O}}$ of carboxyl and devoid any band for ethoxycarbonyl group. When the benzoxazinone 2 was submitted to react with o-phenylene diamine in toleuene yielded the bridge head nitrogen compound $\mathbf{6}$ (Scheme 3). IR spectrum of compound $\mathbf{6}$ devoid any band for ethoxycarbonyl group.<smiles>[R]C(=Nc1ccccc1C(=O)[O-])Nc1ccccc1C([R])O</smiles>

Scheme 2

Glycosyl heterocycles and their nucleoside analogues have multiple potential applications. Significant progress with such analogues has led to advances in Cancer chemotherapy and anti-HBV and HIV applications. The lack of an effective therapy to treat hepatitis B virus and HIV infections, particularly in chronic cases, has focused considerable effort into the synthesis of nucleoside analogues possessing antiviral activity [17-19]. Some analogues having either modified bases and/or glycosyl residues have shown promising antiparasitic chemotherapy [20]. An area of intensive research is in the design of nucleoside analogues where in the aglycone moieties are altered while biological activity is retained. This type of novel design of nucleoside analogue pertains to modified nucleobases which are of neither the purine nor pyrimidine types. In this regards, quinazolin-4(3H)-one (benzopyrimidine derivative) ring has attracted our attention. Thus, when compound 2 was allowed to react with glucoseamine hydrochloride in dry pyridine yielded 3-glycosyl-2- $N$ glucosylcarbamoyl quinazoline 7 (Scheme 3). 
<smiles>NC(=O)c1nc2ccccc2c(=O)[nH]1</smiles>

(3)<smiles>[Mg][Mg]</smiles><smiles>O=C(NCc1ccccc1)c1nc2ccccc2c(=O)n1Cc1ccccc1</smiles>

(4)<smiles>CC(C)(C)C1CC1</smiles><smiles>CCOC(=O)c1nc2ccccc2c(=O)o1</smiles>

(2)<smiles>[R]NC(=O)C(N[R])Nc1ccccc1C(=O)O</smiles>

$\uparrow \mathrm{a}, \mathrm{R}=\mathrm{C}_{2} \mathrm{H}_{5}$

$\mathrm{R}=\mathrm{C}_{5} \mathrm{H}_{10}$

c, $\mathrm{R}=\mathrm{CH}_{2} \mathrm{CH}_{2} \mathrm{OH}$<smiles>OCCI</smiles><smiles>O=c1[nH]c2ccccc2n2c(=O)c3ccccc3nc12</smiles>

(6)<smiles>O=C(NC1C(O)OC(CO)C(O)C1O)c1nc2ccccc2c(=O)n1C1C(O)OC(CO)C(O)C1O</smiles>

(c) $\mathrm{RNH}_{2} / \mathrm{EtOH}$ (a) $\mathrm{HCONH}_{2}$

(b) $\mathrm{PhCH}_{2} \mathrm{NH}_{2} / \mathrm{EtOH}$

(e) glucosamine $\mathrm{HCl}$ / pyridine

(f) $\mathrm{N}_{2} \mathrm{H}_{4} / \mathrm{EtOH}$<smiles>NNC(=O)c1nc2ccccc2c(=O)n1N</smiles>

(8)

\section{Scheme 3}

Heating 4H-3,1-benzoxazin-4-one 2 in hydrazine hydrate in boiling ethanol produced the 3-amino-2-hydrazinocarbonyl quinazolinone 8 (Scheme 3). The reaction takes place via heteroring opening followed by cyclisation and nucleophilic attacks by hydrazine on carbonyl group of ethoxycarbonyl function. The above results are in agreement with our assumption of a nucleophilic attack at $\mathrm{C}(2)$. On the other hand, they are in disagreement with previous results which account for the formation of 3-aminoquinazoline to rationalize the hydrazinolysis reaction in the presence of anhydrous $\mathrm{ZnCl}_{2}$ [21] or when the substituent at $\mathrm{C}(2)$ is sterically bulky [22].

Moreover, quinazolinone derivative $\mathbf{8}$ was used as key starting material for synthesizing Schiff's bases derivatives 9 and 10 via interaction of quinazolinone 8 with aromatic aldehydes like benzaldehyde, 4-methoxybenzaldehyde, 4chlorobenzaldehyde, and 4-nitrobenzaldehyde. Thus, when the quinazolinone derivative 8 was allowed to react with benzaldehyde and/or 4-methoxybenzaldehyde yielded the Schiff's bases 9a,b. On the other hand, 4-chlorobenzaldehyde and 4-nitrobenzaldehyde when submitted to react with quinazolinone 8 afforded the bis compound 10a,b (Scheme 4).

Finally, the quinazolinone derivative 8 was used in synthesis of triazinoquinazolinone. Thus, when compound 8 was submitted to react with phenyl isothiocyanate in boiling dimethyl formamide afforded the triazino-quinazolinone derivative 11 (Scheme 4). 


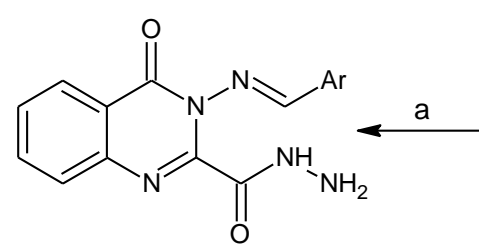

$(9 a, b)$<smiles></smiles>

(8)<smiles>CN(C)C1N/C(=N/c2ccccc2)N(NC(=S)Nc2ccccc2)C(=O)c2nc3ccccc3c(=O)n21</smiles>

(11)
$(10 a, b)$ $\mathrm{a}, \mathrm{Ar}=\mathrm{C}_{6} \mathrm{H}_{4} \cdot \mathrm{Cl}(4)$

b, $\mathrm{Ar}=\mathrm{C}_{6} \mathrm{H}_{4} \cdot \mathrm{NO}_{2}$ (2) $\mathrm{a}, \mathrm{Ar}=\mathrm{C}_{6} \mathrm{H}_{5}$

b, $\mathrm{Ar}=\mathrm{C}_{6} \mathrm{H}_{4} \cdot \mathrm{OCH}_{3}(4)$

(a) benzaldehyde or p-anisaldehyde / EtOH

(b) 4-chlorobenzaldehyde or 2-nitrobenzaldehyde / EtOH

(c) $\mathrm{Ph}-\mathrm{N}=\mathrm{C}=\mathrm{S} / \mathrm{DMF}$

\section{Scheme 4}

\section{REFERENCES}

1. A. Krantz, R. Spencer, T. Tam, T. Liak, L. Copp, E. Thomas, S. Rafferty, J. Med. Chem., 33, 464(1990).

2. M. Guetschow, U. Neumann, Bioorg. Med. Chem., 5, 1935(1997).

3. U. Neumann, N. Schechter, M. Guetschow, Bioorg. Med. Chem., 9, 947(2001).

4. M. M. Gineinah, M. A. El-Sherbeny, M. N. Nasr, A. R. Maarouf, Arch. Pharm. Med. Chem., 335, 556(2002).

5. S. El-Meligie, A. El-Ansary, M. M. Said, M. M. M. Hussein, Indian J. Chem., 40B, 62(2001).

6. J. V. Partin, I. E. Anglin, N. Kyprianou, J. Cancer, 88(10), 1615(2003).

7. H. Kikuchi, H. Tasaka, S. Hirai, Y. Lwabuchi, H. Ooi, S. Hatakeyama, H. S. Kim, Y. Wataya, Y. Oshima, J. Med. Chem., 45(12), 2563(2002).

8. S. Eguchi, T. Suzuzi, T. Okawa, Y. Matsushita, Y. Okamoto, J. Org. Chem., 61, 7316(1996).

9. J. Bergman, J. Chem. Res., 224(S)( 1997).

10. M. E. Azab, E. A. Kassab, M. A. El-Hashash, R. S. Ali, Phosphorus, Sulfur, and Silicon and the related Elements, 184(3), 610(2009).

11. F. K. Mohammed, H. M. Bakeer, M. A. El-Hashash, Asian J. Chem. 21(7), 5004(2009).

12. M. A. El-Hashash, Y. A. El-Badry, Helv. Chim. Acta, 94, 389(2011).

13. M. A. El-Hashash, D. B. Guirguis, Y. A. El-Badry, Der Pharma Chemica, 3, 147(2011).

14. M. A. El-Hashash, K. M. Darwish, S. A. Rizk, F. A. El-Bassiouny, Pharmaceutical 4, 1032(2011).

15. A. M. F. Eissa, A. M. El-Metwally, M. A. El-Hashash, A. M. F. El-Gohary, J. Korean Chem. Soc., 72, 328 (2008).

16. M. A. El-Hashash, T. M. Abdel-Rahman, Y. A. El-Badry, Indian J. Chem. 45B, 1470(2006).

17. C. Perigaud, G. Gosselin, Imback J. Nucleosides Nucleotides, 11, 903(1992).

18. C. K. Chu, S. J. cutler, J. Heterocycl. Chem. 23, 289(1988).

19. R. J. Remy, J. A. Secrist, Nucleosides Nucleotides, 4, 411(1985).

20. M. Maccoss, R. L. Tolman, W. T. Ashton, A. F. Wagner, J. Hannah, A. K. Field, J. D. Karkus, J. I. Germershausen, Chem. Ser. 26, 113(1986).

21. H. M. F. Madkour, M. A. I. Salem, T. M. Abdel-Rahman, M. E. Azab, Heterocycles, 38, 57(1994).

22. H. M. F. Madkour, Arkivoc, 1, 36(2004). 